\title{
Festansprachen anlässlich des Festakts
}

\section{Mai 1998, Zehntentrotte Küsnacht}

\section{Festansprache 1}

Brigitte Spillmann, Präsidentin des Curatoriums des C.G.-Jung-Instituts

Sehr geehrte Frau Gemeinderätin, sehr geehrte Herren Kantonsräte, liebe Angehörige und Erben der weitverzweigten Familie Jung und hier vor allem liebe Frau Hörni -, liebe Gäste und Freunde, liebe Studierende, liebe Kolleginnen und Kollegen, meine sehr verehrten Damen und Herren,

Gerne würde ich Sie alle im Namen des Kuratoriums persönlich begrüssen; ja, es fällt mir tatsächlich schwer, die vielen bekannten und vertrauten Gesichter aus dem näheren und weiteren Umfeld unseres Instituts, ebenso wie aus Politik und Berufspolitik, unter Ihnen allen nicht besonders zu erwähnen. Aber ich glaube, Sie sind mit mir einig, das Wetter ist viel zu schön, als dass wir so lange hier drin bleiben möchten!

Dennoch haben wir Anlass, einen Augenblick zu verweilen. 50 Jahre alt wird das C.G.-Jung-Institut Zürich in diesen Tagen. Nach sieben mal sieben Jahren war das 50. Jahr schon in biblischen Zeiten ein Jubeljahr, eine Zeit der ungeteilten Freude - damals über die Befreiung von aller Mühsal. Heute allerdings können wir uns nicht so rückhaltlos ein ganzes Jubeljahr gönnen; zu viele brennend wichtige Fragen zu Ausbildung und Berufsausübung sind offen, zu viele Aufgaben im politischen und institutionellen Umfeld wollen dringend gelöst werden. Wenn wir uns am heutigen Tag nun aber - entgegen unserer professionellen Verpflichtung - nicht in erster Linie daran machen, diese Probleme bewusst anzugehen,

\section{KARGER}

(ㄱ 1996 S. Karger AG, Basel

Fax + 41613061234

E-Mailkarger@karger.ch

www. karger.com

Accessible online at:

http://BioMedNet.com/karger 
hat das für einmal nichts mit unbewussten Abwehrstrategien zu tun, sondern ganz einfach mit dem Wunsch, uns über das Erreichte zu freuen - tatsächlich zu jubilieren.

Wenn Jung den Gründungstag seines Instituts seinerzeit mit einer gewissen Genugtuung einen «memorablen Tag» genannt hat, war das nicht ganz selbstverständlich - bekanntlich tat er sich lange Zeit schwer mit dem Gedanken, es könnte eines Tages «Jungianer» geben. Sarkastisch hat er sich denn auch in einer seiner früheren Schriften schon ausgelassen über die «Jünger», die bescheiden einem Meister zu Füssen sitzen und sich vor eigenen Gedanken hüten würden. Und er beschrieb deren Tendenz, sich zusammenzuschliessen, «nicht etwa aus Liebe, sondern aus dem wohlverstandenen Interesse, durch Erzeugung einer kollektiven Zusammenstimmung mühelos in der eigenen Überzeugung gefestigt zu werden». Wenn er 1948 schliesslich dennoch einer Institutsgründung zustimmte, so sicher einmal in der Hoffnung, seiner Komplexen Psychologie ein Gefäss für Forschung und Ausbildung zu schaffen, zum andern aber auch aus der Einsicht heraus, dass Individuum und Gesellschaft aufeinander angewiesen sind. Eine solche Überlegung sei der Ausgangspunkt für die Gründung des Zürcher Instituts gewesen, teilte er in seiner Korrespondenz auch ausdrücklich mit. Dass er uns dabei nicht einfach die Rolle der unbedarften, dafür aber umso gläubigeren «Jünger» zugedacht hat, können wir u.a. seinem Erinnerungsbuch entnehmen, wo er sagt, Gemeinschaft blühe nur dort, wo jeder einzelne sich seiner Eigenart erinnere und sich nicht mit den andern identifiziere. Wir sind also auch als Institutsangehörige keineswegs zur Harmonie der «kollektiven Zusammenstimmung» verurteilt, sondern dürfen - erlöst zur Gegensätzlichkeit - auch viel Konflikthaftes miteinander austragen, wenn unsere Gemeinschaft lebendig bleiben und blühen soll.

Seit jenem «memorablen Tag» haben bereits mehrere Generationen Analytikerinnen und Analytiker dieses Institut getragen und geprägt, zuerst in Zürich und dann, als die beengten Raumverhältnisse an der Gemeindestrasse der wachsenden Zahl der Studierenden nicht mehr zu genügen vermochten, seit 1979 in Küsnacht, wo das Jung-Institut grosszügig Wohnrecht bei der Gemeinde im wunderschönen «Seehof» erhalten hat.

Der heutige Tag ist darum nicht zuletzt auch Anlass zu grosser Dankbarkeit gegenüber allen, die unser Institut in ihrer Weise fördern und unterstützen; Dankbarkeit empfinden wir insbesondere auch allen Kolleginnen und Kollegen gegenüber, die das Institut zu dem haben werden lassen, was es heute ist. Ich denke hier in erster Linie an die vielen Dozentinnen und Dozenten, die Ausbildung und Forschung gewährleistet haben, ich denke aber auch an die verschiedenen Mitglieder des Kuratoriums, die das Institut geleitet haben, und dessen Präsidenten, von denen ich namentlich die drei meiner Vorgänger erwähnen möchte, die heute unter uns sind: Adolf Guggenbühl-Craig, Helmut Barz und Paul Brutsche. Unsere 
Dankbarkeit gilt ebenso all den vielen andern Institutsangehörigen und nicht zuletzt auch der Erbengemeinschaft Jung, die unserem Institut nach wie vor mit wohlwollendem Interesse verbunden ist. Sehr dankbar erinnern wir uns heute aber vor allem ganz besonders jenes Mannes, dem wir die Institutsgründung überhaupt verdanken: Carl Gustav Jung. Er hat uns ein unerschöpflich reichhaltiges Werk hinterlassen, das in seiner Genialität wie in seiner Widersprüchlichkeit ein breites, fruchtbares Fundament für alle weitere Entwicklung der Analytischen Psychologie und Psychotherapie gelegt hat.

Dear Students, dear Colleagues, Ladies and Gentlemen,

It is a great pleasure to welcome you all to this celebration of the 50th anniversary of our C.G. Jung Institute in Küsnacht today. This Institute has been open to the far reaches of the world from its very beginnings in 1948.

A large number of foreign students came to the original location on Gemeindestrasse for training in Analytical Psychology. They returned to their home countries and, in particular, to a number of North American cities, with their knowledge of C.G. Jung's complex psychology and it is no surprise that today there are a large number of Jung Institutes to be found in the USA. I should, however, mention that the very first Jung Institute to be founded was not ours, but that of San Francisco, which began a few months earlier and is now in its fifty-first year! While interest in Jungian Psychology has taken many directions, the greatest interest is still today to be found in the USA.

Sigmund Freud and Jung were both of the opinion that the fate of psychoanalysis and psychotherapy would be decided in Germany. As Old Europeans, they apparently did not reckon with the so-called New World in the way that we do today.

The many countries of origin of our trainees clearly reflect that the depth psychology taught by Jung is in demand throughout the world. At present, our students come from 38 different countries, most from Germany and Switzerland, followed by those from the USA, Canada, Italy, Sweden, Japan, Australia, including several from Brazil and, in recent times, Eastern Europe. From Analytical Psychology's historical roots in Zurich, there are today well over 2,000 Jungian analysts and many training institutes throughout the world, including Africa.

But even with these many possibilities for training available in other places, our Institute still continues to be very sought after: people from far-off lands come to Küsnacht for many reasons, but common to them all seems to be a desire for contact with the original source, the place where Jung lived and worked for most of his life: here they are also able to meet some of the few people still alive who lived and worked with Jung, those who knew him personally.

All of these guests are very welcome visitors: they help us to leave behind the sometimes narrow borders of our small country and to keep us in touch with

$\overline{250} \quad \overline{\text { Anal Psychol 1998;29:248-255 }} \quad$ Festansprachen 
the wider world. In our exchanges with them, our colleagues from some of the far corners of the earth, we are reminded of the universal appeal of Jung's approach, we are confronted with a variety of other ways of understanding the world, and we continue, together, to concern ourselves with the mysteries of the human soul.

But today is not the day for pursuing great truths. Today we would just like to joyfully celebrate, and we are very happy that so many of you from other places have come to be with us on this special day. In the name of the Curatorium and all of us at the Zurich Institute in Küsnacht, I would like to thank you for joining us and I hope that we will have a wonderful celebration and party!

Chers collègues de langue française,

A vous aussi j'aimerais dire quelques mots dans votre langue. Nous nous considérons comme un institut international et cependant, vous, collègues francophones, surtout ceux de Suisse romande, vous vous étonnez, non sans une certaine amertume parfois, que votre langue soit très peu employée à l'Institut et qu'elle ne soit pas reconnue comme langue officielle. Personnellement je le regrette et je ne suis pas la seule; ne considérez pas ce fait comme un manque d'estime, mais plutôt comme un signe de nos limites! Il serait en effet fort difficile d'offrir un programme complet de cours en français en plus de nos programmes allemand et anglais.

Fort heureusement des collègues de la Suisse romande, diplômés de notre Institut, ont uni leurs forces pour fonder «l'Antenne Romande» qui organise régulièrement des manifestations autour de la psychologie jungienne.

C'est justement à un auteur de langue française que nous devons une réflexion profonde sur un ancien mythe à même de nous accompagner, nous psychothérapeutes et membres de cet Institut, dans nos efforts incessants: je veux parler de Camus qui a su redonner vie et sens au mythe de Sisyphe: quelle meilleure définition de notre activité et quel meilleur encouragement dans son exercice que sa célèbre suggestion: «Il faut s'imaginer Sisyphe heureux».

\section{Liebe Gäste,}

Ein so denkwürdiger Geburtstag wie der Fünfzigste lässt wohl stets so etwas wie ein Gefühl der Ernte aufkommen - und es ist ja vielleicht nicht ganz zufällig, dass wir heute in der Zehntentrotte feiern, einem Ort, wo traditionellerweise Ernte eingebracht wurde. Sie alle kennen ja gewiss auch solche Momente in Ihrem persönlichen Leben, wo man dankbar innehält und staunend feststellt, was alles erreicht ist. Im Alltag allerdings entspricht uns wohl eher Sisyphus, den wir uns eben glücklich vorstellen müssen. Das meint wohl auch das jüdische Sprichwort, das ich Ihnen abschliessend vermitteln möchte: «Und wenn einmal alles erreicht 
ist, ist nichts erreicht als ein Anfang von vorn». Lassen Sie uns also erneut von vorn beginnen - allerdings erst morgen - heute wollen wir mit Ihnen allen ein fröhliches Fest feiern!

\section{Festansprache 2}

\section{Victoria Yeganeh}

When I was asked to speak briefly today, I asked myself what is really special about this Institute for the 'English-speaking-students' in particular. What is it that we would like to highlight and celebrate today on this 50th anniversary?

'English-speaking students' - sounds quite self-explanatory, doesn't it? The name for the group of students who take their classes in English rather than in German. It is a convenient term and I can't think of a better one. But it also hides a lot. What it really means is that these students are more fluent in English than in German. But it doesn't mean - for everyone, at least - that English is their first or native language. Linguistic diversity is just the beginning of what this term hides.

This group of people - the 'English-speaking students' - are a particularly diverse group in many ways. Over the next few minutes, let me try to give you some idea. And let me try to explain the special nature of our relationship with this unique Institute.

When each of us comes here to Küsnacht, we bring with us from our own countries a richness of culture and language. And we bring it to mix and mingle with what others bring and with what we find here waiting for us in Zurich and in Switzerland.

Just to give you an idea of the range of different countries that we come from - let me work my way around the extremes of an imaginary world map. At the moment, there are students here from England and Ireland, Norway, Russia, Japan, Australia (my home!), South Africa and North and South America (I think that's about circumambulated the globe!).

Another distinguishing feature of this Institute of special significance to the English-speaking students is its broad admission policy - it's openness (in fact, more than openness - desire) to take people from a wide variety of educational and professional backgrounds. (When we students get together and talk about what it is we 'used to do', we call it 'past lives'.) Again - all the different points of view give more richness for all of us.

Not only are there people here from the various healing arts and sciences, but there are also creative artists, scientists, educators and business people. And other fields, too! It's a very exciting place to be.

$\overline{252} \quad \overline{\text { Anal Psychol 1998;29:248-255 }} \quad$ Festansprachen 
When I was thinking about what it's like to be here now in 1998, I was interested to see what Jung had to say about the Institute's early days. In his introduction to the first publication from the new Institute, he wrote that 'psychology ... is the intermediary between the disciplines ... psyche is the mother of all the sciences and arts. Anyone who wishes to paint her portrait must mingle many colours on his palette' [CW 18, $\$ 1163$ ].

This view is honoured so richly in the diversity of the student body of this Institute and also in the magnificent opportunities for learning that are made available to us.

The Institute is truly a melting pot - and the setting at Seehof makes it a very beautiful and soulful one. A melting pot to hold the diversity and to provide a container (and sometimes even a source of heat!) for the alchemical transformations that take place in the soul and psyche of everyone who comes here.

Many of us in the program need to live away from our homes for an extended period - leaving our friends and families and support networks sometimes thousands of kilometres away. Because of this, our immersion in this melting pot can be virtually total. Anyone who comes here thinking they are here 'just to be trained' or to 'get another qualification' learns very quickly. This place is special. That's why we are drawn here in the first place. And our lives are inevitably changed from the encounter.

So today, we celebrate the 50th anniversary of this unique and rich focus of transformation and learning that we call the 'Jung Institute'. And we look forward, with interest and affection and support to see what the next decades will bring.

So, on behalf of all the English-speaking students, a final word to all the associates and friends of the Institute here to celebrate today: 'Willkommen!'

\section{Festansprache 3}

Ulrich Gundermann

Ich möchte die Gelegenheit für ein paar Anmerkungen zur Empirie des Individuationsprozesses unter institutionalisierten Bedingungen nutzen, kurz, ich möchte ein paar Worte zu den praktischen Bedingungen sagen, unter denen viele von uns im deutschsprachigen Programm sich hier ausbilden.

Individuation ist kein leeres Wort hier im Institut. Das wurde mir bereits in den Gesprächen mit der Auswahlkommission deutlich. Da sassen drei grundverschiedene Menschen und keine Einheits-Jungianer. Das bestärkte mich in meiner Überzeugung, mich auf den richtigen Weg gemacht zu haben.

Das Institut selbst kam mir auf den ersten Blick vor wie eine alte Dame. War es eine Inkarnation von Sophia oder der Grossen Mutter? Liegend am 
Ufer des Zürich-Sees, dieses schönen und anschaulichen Symbols für das Unbewusste.

Auch deshalb so geeignet als Beispiel für unsere zukünftige Arbeit, weil auch der Zürich-See einmal bedenklich verschmutzt war durch Folgen des gesellschaftlichen Lebens, die nicht geklärt, sondern verdrängt wurden. Jetzt tummeln sich die lebendingen Inhalte, die Fische, wieder, und mit ihnen im Sommer so manche angehende Analytiker.

Der Alltag jedoch ist eher von der Aufgabe der Gegensatzvereinigung geprägt: leben und arbeiten in Freiburg/Deutschland (in meinem Fall, in Mailand oder München oder sonstwo in anderen) und studieren hier. Manchmal scheint das ein fast unvereinbarer Gegensatz, doch zuverlässig erscheint im Moment höchster Anspannung das rettende Symbol: der Zug. Er bietet gleichzeitig ein Kriterium dafür, welche Theorien über das Wesen der menschlichen Seele mich wirklich zu fesseln vermögen, nämlich diejenigen, die mich meine Mitreisenden im Zug vergessen lassen.

Auf tieferer Ebene zeigt sich das Problem der Gegensatzvereinigung darin, während eines Lebens vollgestopft mit Terminen und Pflichten, Prüfungen und Berichten, äussere und innere Räume zu erhalten und zu entwickeln, um zur Ruhe und zu sich zu kommen. Zeit zu haben, für das von Jung mit Recht so betonte Beobachten des eigenen seelischen Prozesses.

Gelingt es einmal weniger gut, dann bietet so ein Weg genug Gelegenheit zu jeder Art von Schattenprojektionen. Wenn Geld und Zeit knapp sind, so liegt der Gedanke nahe, dass die anderen daran schuld sind, seien es nun die Krankenkassen oder Gesundheitsminister, die SBB oder das Institut selbst. Ist ja auch wirklich gar nicht so leicht auseinanderzuhalten in unserer, von Einsparungen und Machtkämpfen im Gesundheitswesen geprägten Zeit, wo es gilt, besser mit Schwierigkeiten umzugehen und wo es nötig ist zu kämpfen.

Manchmal fragt man sich dann: «Warum mache ich das eigentlich, bin ich irgendeinem Komplex verfallen oder wirklich so animiert?» Zum Glück gibt es ja ganz schön viele, die da im deutschsprachigen Programm auf dem gleichen Weg sind. Das hilft. Doch normalerweise laufen sie, wenn man ihnen begegnet, gerade in die andere Richtung.

Gäbe es nicht die Wochenendseminare und im zweiten Ausbildungsabschnitt die Kontrollfallkolloquien, so würde man wohl kaum eine oder einen der anderen kennenlernen. Jung war ja, wie wir auch vorhin wieder gehört haben, ausgesprochen skeptisch gegenüber jeder Form von Kollektivierung, doch ich meine, diese Gruppen haben eine wesentliche Funktion in der Belebung und Stützung von Anima bzw. Animus.

Angesichts nicht freundlicher werdender äusserer Bedingungen wäre es möglicherweise sinnvoll, sich beim Entstehen solcher Gruppen auch im ersten Ausbildungsabschnitt nicht nur auf die steuernden Kräfte des Selbst zu verlassen, son-

$\overline{254} \quad \overline{\text { Anal Psychol 1998;29:248-255 }}$ Festansprachen 
dern ihnen von vornherein aktiv mehr Raum einzuräumen, denn Individuation geschieht auch in der Begegnung, und zwar nicht nur in der Begegnung Analytiker-Analysand.

Aber Begegnung steht ja erfreulicherweise auch heute auf dem Programm. In welchem Lebensalter sich die «alte Dame» C.G.-Jung-Institut nun gerade befindet ist ja noch völlig offen. Ich nehme mal an, die Lebensmitte ist noch lange nicht erreicht und wünsche ihr bei der nicht einfachen Aufgabe der Gegensatzvereinigung, nämlich einerseits die Grundlagen der Jungschen Psychologie in ihrer Tiefe und Schönheit zu wahren und andererseits für Weiterentwicklungen und die Auseinandersetzung mit der heutigen gesellschaftlichen Realität offen zu bleiben, von Herzen alles Gute. 